\title{
Modeling of construction waste processing system development
}

\author{
Pavel Oleinik, Tatyana Kuzmina*, Viktor Zenov and Vitaliy Melnichuk \\ Moscow State University of Civil Engineering, Yaroslavskoe shosse, 26, Moscow, 129337, Russia
}

\begin{abstract}
Construction waste is the most important source for reducing raw material resources. In this regard, many countries conduct large-scale research in developing progressive construction waste utilization technologies and creating highly efficient production equipment. Current experience in this field views the construction waste processing system as a number of interconnected subsystems: organizational and technical preparatory measures; waste collection and sorting; waste containerization, packaging and transportation; waste processing and manufacturing of recyclable resources. Each sub-system consists of a set of measures which characterize the change in material quality and properties. Modeling of the construction waste processing system addresses the task of assessing the actual level of the system and subsystems and determining the condition of the same within certain forecasted time perspectives. For this purpose, the cost vs. revenue comparison tools are used. To develop the construction waste processing system and maintain it in working condition it is important that, early on in the project, a waste classification catalogue and a relevant glossary of terms be compiled with all waste processing contractors having to agree to it and observe it. Also, a data bank containing all the relevant engineering and process documentation shall be drafted and maintained
\end{abstract}

\section{Introduction}

Annually over 5 billion cubic meters of construction waste is processed into a valuable raw material internationally, which allows for construction and reconstruction costs for building and structures to be significantly reduced, raw material resource consumption to be cut down, landfill capacities to be spared and ecology to be improved [1,2].

The bulk of construction waste in Russia comes from construction operations due to rebuilding and repair projects of buildings and structures $-65.8 \%$, demolition and dismantling facilities $-29.3 \%$ of the total volume of construction waste. While the share of construction waste in new construction accounts for $1.4 \%$, construction companies report the figure not exceeding $3.5 \%$ accounted for by rejects and discarded items of reinforced concrete structures. The construction waste nomenclature includes 21 types of waste, among which concrete and reinforced concrete waste, scrap brick, scrap asphalt prevail (Table 1).

\footnotetext{
Corresponding author: KuzminaTK@mgsu.ru
} 
Table 1. Waste classification by 'material composition'

\begin{tabular}{|c|c|c|}
\hline Group & Subgroup & Nomenclature \\
\hline 1 & 2 & 3 \\
\hline \multirow[t]{2}{*}{$\begin{array}{l}\text { Organic-based } \\
\text { waste }\end{array}$} & Wood waste & $\begin{array}{l}\text { Wood-based materials and constructions, wood- } \\
\text { based heat-insulation materials, chipboard, ply- } \\
\text { wood, HDF, MDF, joinery products, wooden con- } \\
\text { tainers etc. }\end{array}$ \\
\hline & $\begin{array}{l}\text { Paper and cardboard } \\
\text { waste }\end{array}$ & $\begin{array}{l}\text { Paper-based wallpaper, packing paper, paper-board } \\
\text { container }\end{array}$ \\
\hline \multirow{8}{*}{$\begin{array}{l}\text { Mineral-based } \\
\text { waste }\end{array}$} & \multirow{3}{*}{$\begin{array}{l}\text { Natural stone-based } \\
\text { waste }\end{array}$} & cladding panel scrap \\
\hline & & Stonemasonry slurry waste \\
\hline & & $\begin{array}{l}\text { Curb stone, paving stone, cobble stone scrap and all } \\
\text { the rest of natural stone-based waste }\end{array}$ \\
\hline & \multirow{5}{*}{$\begin{array}{l}\text { Concrete and cement- } \\
\text { based waste }\end{array}$} & Reinforced concrete waste \\
\hline & & Heavy-weight concrete waste \\
\hline & & Light-weight concrete waste \\
\hline & & Aerated concrete waste \\
\hline & & Fiber, papercrete and cement boards waste \\
\hline & \multirow[t]{3}{*}{$\begin{array}{l}\text { inorganic binder- } \\
\text { based waste }\end{array}$} & $\begin{array}{l}\text { Alabaster-based materials waste (panel and board } \\
\text { partitions, gypsum boards, ventilation blocks) }\end{array}$ \\
\hline & & Silicate materials waste (bricks, aerated materials) \\
\hline & & $\begin{array}{l}\text { Calcareous-based materials waste (lime-sand, lime- } \\
\text { slag and lime-ash materials) }\end{array}$ \\
\hline & $\begin{array}{l}\text { Asbestos-cement } \\
\text { waste }\end{array}$ & $\begin{array}{l}\text { roofing sheets, cladding panels, pipes, ventilation } \\
\text { blocks, electro-technical boards }\end{array}$ \\
\hline & Glass-based waste and & Glass scrap \\
\hline & \multirow[t]{3}{*}{ equated waste } & Foam glass waste \\
\hline & & Silicate and glass wool waste \\
\hline & & Perlite and vermiculite products waste \\
\hline & Ceramic-based waste & $\begin{array}{l}\text { Scrap brick, scrap ceramic sanitary ware, scrap } \\
\text { faience and ceramic tiles }\end{array}$ \\
\hline \multirow[t]{8}{*}{$\begin{array}{l}\text { Chemical-based } \\
\text { waste }\end{array}$} & $\begin{array}{l}\text { Asphalt and bitumi- } \\
\text { nous concrete waste }\end{array}$ & Scrap asphalt \\
\hline & $\begin{array}{l}\text { roll roofing and wa- } \\
\text { terproof materials } \\
\text { waste }\end{array}$ & $\begin{array}{l}\text { Bituminous, tar, bitumen-tar, polymeric-bitumen, } \\
\text { rubber-tar and bituminous unsupported materials } \\
\text { (sealing membrane) and cardboard-based materials } \\
\text { (bituminous waterproofing, asphalt roofing paper, } \\
\text { tarpaper), glass-based materials (fiberglass roofing } \\
\text { material), asbestos paper-based materials (asbestos- } \\
\text { based asphalt felt) }\end{array}$ \\
\hline & \multirow{3}{*}{$\begin{array}{l}\text { Plastic and polymer } \\
\text { waste }\end{array}$} & Linoleum, vinyl tiles waste \\
\hline & & Polymer roofing materials waste \\
\hline & & $\begin{array}{l}\text { foam plastic, porous foam waste (polystyrene, pol- } \\
\text { yurethane) }\end{array}$ \\
\hline & \multirow[t]{3}{*}{$\begin{array}{l}\text { Plastic and polymer } \\
\text { waste }\end{array}$} & $\begin{array}{l}\text { Plastic water supply pipes, drainage and electrical } \\
\text { conduit }\end{array}$ \\
\hline & & Hand railing and staircase railings \\
\hline & & Polymer-based molding waste \\
\hline
\end{tabular}

For the EU zone average rate in weight percent accounts for $57 \%$ of scrap brick, $37 \%$ of concrete and reinforced concrete waste, $2 \%$ of wood waste. 


\section{Methods}

In many parts of the world, for example, in Germany, Holland, Belgium, Japan, etc., landfills are never used for dumping construction waste. Under the existing laws of these countries, waste grinding and recycling should be carried out at the demolition site [3]. Diverse and large-scale research in developing progressive construction waste utilization technologies $[4,5,6]$ and creating highly efficient production equipment $[7,8]$ have a great impact on construction waste processing system development. As a result, developed rules regulate the use of recycled crushed stone and sand; recycled aggregate determination of the concrete mix compositions; parameter estimation of recycled materials [1, 9].Particularly, experience and results of such companies as Parker Plant Ltd (England), 'Agrikon' (USA), 'Stincorol' (Holland) etc. are widely used. The first stationary disposal plant was built in Holland in 1970. Currently, there are over 50 stationary plants in operation in this country. Machine-building enterprises of the country designed equipment for work in urban settings with minimal environment impact. For example, 'City'-like equipment has a number of advantages like usage of environmental friendly hydraulic system fluids and oiling; it's low-noise; it's fitted out with highly-efficient dedusting system of working area $[10,11]$. First-class factories assembling crushing and screening plants can be found in Austria. For example, 'Maschinenfabrik Liezen und Gieberei Ges.m.b.H (MFL)' is the leading European equipment manufacturer for grinding and processing of minerals and recycled construction material scrap. Austrian companies have innovative production facilities, fitted out with high-performance equipment and technical instruments, which allow producing a vast range of crushing and screening plants on a turnkey basis $[12,13,14]$.

In many countries, the primary importance to the issue of construction waste processing consists of sound policy of tax on land, occupied by dumps and landfills; and stimulation system, used by manufacturers, who process waste. In this vein in 1992 Canada passed the law on increasing tax on land, occupied by environmental friendly waste. Waste recycling is not just an alternative to mineral raw materials but it also can reduce environmental damage. This results in reduction in volume of mineral raw materials extraction, which is closely connected with decrease of land exploitation, conservation of all types of natural resources and landscape. The ecological situation of cities improves due to recycling waste production conducting demolition works. Therefore, this direction of waste processing has been developing successfully for many years $[4,11]$.

A series of countries (Germany, Holland, etc.) elaborates and passes waste laws, where mandatory quota of residual materials is determined, in order to use obligatorily construction waste as raw material. However, quota rate grows higher with every passing every year. For example, in Germany processing and realization quota accounts for $60 \%$ of construction waste, $40 \%$ of construction facility waste, $90 \%$ of road construction waste.

In Russia until 1990, construction waste was almost never recycled. The bulk of it was buried in landfills. The situation has changed radically by now. The leader in this direction is Moscow building complex. Due to the rise of the construction industry, construction waste production began to increase rapidly since 1994 in Moscow. For example, about 2 million 51 thousand tons of construction and demolition waste were received on just commercial orders in 2003. Today construction waste volume is about 10 million tons. As practice shows, crushing and screening complexes in Moscow are constantly increasing processing construction waste capacity. Around 40\% of scrap concrete was recycled in 2003, in comparison with about $85 \%$ in 2016 . Scrap metal waste just as glass waste comes in great volumes, and a number of organizations ('Vtortsvetmet', 'Vtormet', etc.) receive them for recycling.

There are two technological schemes in forming construction waste processing facilities - stationary and mobile plants. Stationary plants are based, as a rule, in industrial zones, 
and they are not linked to specific objects. These plants are fitted with stationary equipment; construction waste is delivered there by road, rail or water. Stationary plants are typical of large cities and are intended to process concrete and reinforced concrete waste, asphalt concrete, scrap brick, granite waste, etc.

Mobile plants include relocatable and transportable units, and it is recommended that these are installed in the areas of mass demolition of buildings and structures. Relocatable units consist of several modules, which should be installed on a foundation. The units have a loading bin, flight conveyer, sorting drum, magnetic separator, grinder, etc. Caterpillartracked and wheel-mounted mobile units are manufactured by machine-building industry. These units have power-plant, a charging bin, grinder, magnetic separator, conveyor system, sorting drum.

Domestic and foreign experience shows that it is possible to avoid negative implications of the formation and accumulation of construction waste only by controlling all the processes of collecting, sorting, transporting and processing wastes, combined by tasks and objectives and fit in with city (district) general sanitation plan. This system can be represented as a system for processing construction waste on the base of inter-related measures, tasks and objectives of organizational, technical, technological, economic and social principles, providing systematic and continuous collecting, sorting, transporting and processing of construction waste; and recycled raw material with preplanned technical-and-economic indexes.

The system is rooted in purposeful activities of customer service, construction, engineering, transport, supply organizations and processing companies; due to actions coordination, balanced labor and material-technical resources; guaranteed execution of planned volume of development and realization of recycled raw material.

Structurally the construction waste processing system should consist of the following subsystems:

organizational and technical support;

waste collecting and sorting;

waste containerization, packaging and transportation;

waste processing and output of recycled resources.

When creating the construction waste processing system one should consider the following:

wide range of construction waste based on materials and their combinations;

wide range of collecting, sorting, delivering and processing waste forms and methods;

territorial dispersion of the waste acceptance and processing enterprises;

restrictions to temporary construction waste storage;

bulk of construction waste accumulation onsite enterprises and landfills.

According to its goals the construction waste processing system can be divided at least into three levels.

Level 1 has four main goals - environmental safety, assurance of recycled materials quality, labor costs minimization, profit-maximization.

At level 2 environmental safety can be achieved by constant monitoring of environment, effectiveness of laws and regulations, compliance with the requirements of waste burial. First, compliance with technology regulations and appropriate work of quality control unit are the basic key to succeed in recycled materials quality. Labor saving, personnel development, rational resources concentration, constant delivery organization of construction waste and stability of market conditions are of great importance with regard to labor costs minimization and profit-maximization.

Level 3 is different from the levels above as it has more sub-goals. Ecological appraisal, construction waste delivery in closed containers, assessment and punitive sanctions for environment pollution are very important at the stage of environmental safety. Product certifi- 
cation, application of waste-free technology and effective equipment are of exceptional importance for recycled materials quality assurance. These criteria are also crucial for labor costs minimization and profit-maximization sub-levels, where such sub-goals as sorted waste and its constant delivery organization and relevancy of construction industry demand are needed.

Materials and methods of each subsystem are summarized in Table 2.

Table 2. Structure factors of construction waste management system

\begin{tabular}{|c|c|c|c|}
\hline $\begin{array}{l}\text { Subsystem } \\
\text { code }\end{array}$ & $\begin{array}{c}\text { Subsystem } \\
\text { name }\end{array}$ & Factor name & $\begin{array}{c}\text { Factor } \\
\text { code }\end{array}$ \\
\hline 1 & 2 & 3 & 4 \\
\hline$i=1$ & $\begin{array}{c}\text { organizational } \\
\text { and technical } \\
\text { support } \\
\mathrm{P}_{1}\end{array}$ & $\begin{array}{l}\text { Formation and correction of construction waste no- } \\
\text { menclature. } \\
\text { Development of unified requirements for waste man- } \\
\text { agement. } \\
\text { Compilation of the universal terminological glossary. } \\
\text { Development of operating regulations standards. } \\
\text { Engineering and introduction of construction waste } \\
\text { data bank. } \\
\text { Standardization of document format. } \\
\text { Development of unified requirements for material and } \\
\text { process documentation. } \\
\text { Formation of technical and pricing policy package. } \\
\text { Volume of waste production forecast. } \\
\text { Waste output and processing secondary product fore- } \\
\text { cast. } \\
\text { Volume of waste burial forecast. }\end{array}$ & $\begin{array}{l}\mathrm{P}_{11} \\
\mathrm{P}_{12} \\
\mathrm{P}_{13} \\
\mathrm{P}_{14} \\
\mathrm{P}_{15} \\
\mathrm{P}_{16} \\
\mathrm{P}_{17} \\
\mathrm{P}_{18} \\
\mathrm{P}_{19} \\
\mathrm{P}_{110} \\
\mathrm{P}_{111}\end{array}$ \\
\hline$i=2$ & $\begin{array}{c}\text { waste collecting } \\
\text { and sorting } \\
\mathrm{P}_{2}\end{array}$ & $\begin{array}{l}\text { Solution development of construction waste collec- } \\
\text { tion. } \\
\text { Management of waste sorting by material type. } \\
\text { Solution development of construction waste storage. } \\
\text { Compliance with safety regulations. } \\
\text { Monitoring and supervision project of waste collect- } \\
\text { ing and sorting. }\end{array}$ & $\begin{array}{l}\mathrm{P}_{21} \\
\mathrm{P}_{22} \\
\mathrm{P}_{23} \\
\mathrm{P}_{24} \\
\mathrm{P}_{25}\end{array}$ \\
\hline$i=3$ & $\begin{array}{c}\text { waste container- } \\
\text { ization, packag- } \\
\text { ing and trans- } \\
\text { portation } \\
\mathrm{P}_{3}\end{array}$ & $\begin{array}{l}\text { Standardization of specialized containers and packag- } \\
\text { ing devices for delivery of construction waste. } \\
\text { Development schemes for construction waste delivery } \\
\text { into various regions. } \\
\text { Development maintenance requirement card for han- } \\
\text { dling vehicles. } \\
\text { Monitoring and supervision project of handling and } \\
\text { delivery of construction cargo. } \\
\text { Development of a self-loading platform. }\end{array}$ & $\begin{array}{l}\mathrm{P}_{31} \\
\mathrm{P}_{32} \\
\mathrm{P}_{33} \\
\mathrm{P}_{34} \\
\mathrm{P}_{35}\end{array}$ \\
\hline$i=4$ & $\begin{array}{c}\text { waste pro- } \\
\text { cessing and } \\
\text { output of recy- } \\
\text { cled resources } \\
\mathrm{P}_{4}\end{array}$ & $\begin{array}{l}\text { Assessment of the technical level of waste processing } \\
\text { plants } \\
\text { Selection of innovative technologies for processing } \\
\text { construction waste. } \\
\text { Conducting research and advanced development of } \\
\text { new processing of construction waste technology. } \\
\text { Requirements engineering for technological equip- }\end{array}$ & $\begin{array}{l}\mathrm{P}_{41} \\
\mathrm{P}_{42} \\
\mathrm{P}_{43}\end{array}$ \\
\hline
\end{tabular}




\begin{tabular}{|l|l|l|}
\hline & \multicolumn{1}{|l|}{$\begin{array}{l}\text { ment. } \\
\text { Development of recommendations concerning recy- } \\
\text { cled materials field. } \\
\text { Development of operating regulations standards for } \\
\text { construction waste processing. }\end{array}$} & $\mathrm{P}_{44}$ \\
\hline
\end{tabular}

\section{Main part}

The program- and purpose-oriented development model of the processing construction waste system is determined by the system goals dominating over sub-system goals.

Bench-mark data include:

1. Nomenclature code of construction waste $-l=\overline{1, L}$.

2. Construction site (enterprise) code - supplier of construction waste $-i=\overline{1, n}$.

3. Enterprise (landfill site) code, processing construction waste $-j=\overline{1, m}$.

4. Time duration code of the forecasting time period $-\tau=\overline{1, T}$.

5. Cumulative distribution function of current costs for collection, sorting and transportation of construction waste $l$-nomenclature from $i$-construction site in $\tau$ - time duration $\left\{Q_{\text {li } \tau}^{(1)}\right\}$.

6. Cumulative distribution function of capital contributions, invested into project documentation, standardization and containers and vehicle construction etc. for $l$ construction waste nomenclature at $i$-construction site in $\tau$ - time duration - $\left\{Q_{l i \tau}^{(2)}\right\}$.

7. Cumulative distribution functions of current costs for acceptance and processing (burial) of construction waste of $l$ - nomenclature at $j$ - enterprise (landfill site) in $\tau$ - time duration - $\left\{G_{l i \tau}^{(1)}\right\}$.

8. Cumulative distribution functions of capital contributions, invested into $j$ - processing of construction waste enterprise of $l$ - nomenclature in $\tau$ - time duration - $\left\{G_{l i \tau}^{(2)}\right\}$.

9. Cumulative distribution functions of construction waste volume of $l$-nomenclature at $i$-construction site (enterprise) in $\tau$ - time duration - $\left\{V_{l i \tau}\right\}$.

10. Cumulative distribution functions of gain in construction waste volume of $l$ - nomenclature at $i$-construction site in $\tau$ - time duration - $\left\{\Delta V_{\text {li } \tau}\right\}$.

11. Cumulative distribution functions of construction waste volume of $l$-nomenclature, processing (to be buried) at j-enterprise (landfill site) in $\tau$ - time duration - $\left\{W_{l j \tau}\right\}$.

12. Cumulative distribution functions of construction waste volume of $l$ - nomenclature, processing (to be buried) at $j$ - enterprise (landfill site) in $\tau$ - time duration - $\left\{\Delta W_{l j \tau}\right\}$.

13. Cumulative costs for collecting, sorting, transporting and processing (burial) of construction waste of $l$ - nomenclature in $\tau$ - time duration - $\left\{\Phi_{l \tau}\right\}$.

14. Part by volume coefficient of $l$ - nomenclature in one ton (cubic meters) of construction waste $\left\{\alpha_{l}\right\}$.

15. Part by volume gain coefficient of $l$ - nomenclature in one ton (cubic meters) of construction waste $\left\{\theta_{l}\right\}$. 
16. Part by volume coefficient of $l$ - nomenclature during processing (burial) of one ton (cubic meters) of construction waste $\left\{\mathrm{C}_{l}\right\}$.

17. Part by volume gain coefficient of $l$ - nomenclature during processing (burial) of one ton (cubic meters) of construction waste $\left\{\mathrm{d}_{l}\right\}$.

The equation of connection between subsystems of collecting, sorting, transporting and processing of construction waste can be expressed through the costs:

$$
\Phi=Q_{\tau}^{(1)} \cdot V_{\tau}+Q_{\tau}^{(2)} \cdot \Delta V_{\tau}+G_{\tau}^{(1)} \cdot W_{\tau}+G_{\tau}^{(2)} \cdot W_{\tau}
$$

It is required to find the values of $V_{\tau}$ and $\mathrm{W} \tau$, characterizing the interconnections of subsystems development.

In order to simplify the model it is accepted

$$
\begin{array}{rlrl}
V_{\tau} & =\sum_{l=1}^{L} \sum_{i=1}^{n} V_{l i \tau} & Q_{\tau}^{(1)} & =\sum_{l=1}^{L} \sum_{i=1}^{n} Q_{l i \tau}^{(1)} \\
\Delta V_{\tau} & =\sum_{l=1}^{L} \sum_{i=1}^{n} \Delta V_{l i \tau} & Q_{\tau}^{(2)}=\sum_{l=1}^{L} \sum_{i=1}^{n} Q_{l i \tau}^{(2)} \\
W_{\tau}=\sum_{l=1}^{L} \sum_{i=1}^{n} W_{l i \tau} & G_{\tau}^{(1)}=\sum_{l=1}^{L} \sum_{i=1}^{n} G_{l i \tau}^{(1)} \\
\Delta W_{\tau}=\sum_{l=1}^{L} \sum_{i=1}^{n} W_{l i \tau} & G_{\tau}^{(2)}=\sum_{l=1}^{L} \sum_{i=1}^{n} G_{l i \tau}^{(2)}
\end{array}
$$

It's appropriate to assume that the quantities $Q^{(1)}, Q^{(2)}, G^{(1)}$ and $G^{(2)}$ are constant values for the whole time period.

It's appropriate to assume the equation (1) as the difference

$$
\Phi-\left[Q_{\tau}^{(1)} \cdot V \tau+G^{(1)} \cdot W_{\tau}\right]=F
$$

The principle of algorithm development assumes that the first summand interprets development of collecting, sorting, transporting of construction waste subsystems, and the second summand represents development of processing construction waste subsystem.

In such case capacities for processing construction waste should be sufficient at a given time. Therefore, the maximum production capacity is to be selected out of all possible options. As a rule

$$
W_{\tau}=V_{\tau}-V_{\tau}^{(1)}
$$

where $V_{\tau}^{(1)}$ is a part of construction waste to be buried in specialized landfill sites.

As we see from studies and calculations, construction waste processing system development is assured for the whole time period, if for each time duration $\tau=1,2,3, \ldots, \mathrm{t}$ the arrangement of the formula is going to be:

$$
\sum_{\tau=1}^{T} W_{j} \geq \alpha \sum_{\tau=1}^{T} V_{\tau}+\beta \sum_{\tau=1}^{T} \Delta V_{\tau}+c \sum_{\tau=1}^{T} W_{\tau}+d \sum_{\tau=1}^{T} \Delta W_{\tau}
$$

The values of $\alpha, \mathrm{B}, \mathrm{c}, \mathrm{d}$ are determined by the methods of differential calculus:

Where: $\alpha$ is waste volume $l$-nomenclature in 1 ton (cubic meters) of construction waste;

в is waste volume $l$-nomenclature, corresponding to their increase;

$\mathrm{c}$ is waste volume $l$-nomenclature, expendable on obtaining 1 ton (cubic meters) of recycled resource;

$\mathrm{d}$ is waste volume $l$-nomenclature, expendable per unit of capacity of processing enterprises. 
To develop the construction waste processing system and maintain it in working condition it is important that, early on in the project, a waste classification catalogue and a relevant glossary of terms be compiled with all waste processing contractors having to agree to it and observe it. Also, a data bank containing all the relevant engineering and process documentation shall be drafted and maintained. Engineering and introduction of data bank and its functions make possible to outline the main directions of data analysis and metering introduction of a unified register of construction waste, registration of technology regulations for management of construction and demolition waste, the analysis of the current state and growth of construction waste forecast, development of recommendations for effective usage of waste, creation of the system, operating with recycled resources, performance of monitoring functions.

The technical regulations on waste treatment process, as a basic working paper, should be of a standard form and represent the whole waste treatment process, from collection to processing or burial. This regulation is developed separately for each waste production facility.

\section{Conclusions}

Creation of a construction waste processing system is driven by the need to achieve coherence among its partici-pants - customer service, construction, engineering, transport, supply organizations and processing companies.

It is better to represent the structure of construction waste processing system through the main production facili-ties and waste processing as following subsystems - organizational and technical preparatory measures; waste collection and sorting; waste containerization, packaging and transportation; waste processing and manufacturing of recyclable resources.

Each subsystem should consist of a set of measures, which characterize the change in material quality or its properties: waste collection, sorting based on types of material, storage; handling and delivery, processing technologies and manufacture of a recycled product.

The construction waste processing system development strategy should be based on development forecasts, sub-systems of collecting, sorting waste; containerization, packaging and transportation on the one hand, and development of subsystem of processing waste and manufacture of recyclable resources, keeping the balance between them, on the other hand.

\section{References}

1. Aksyonova L.L., Bugayenko L.V, Khlebenskih S.N. Processing and utilization of construction waste to obtain efficient green composites. Modern tendencies of industrial science: III international science conference materials - Kazan, 63-65 (2014)

2. Koloskov V.N., Oleynik P.P., Tikhonov A.F., Dismantling residential units and processing their structures and materials for secondary use. Publishing house 'Civil Engineering Institute', 199 (2004)

3. Oleinik P.P., Grigorieva L.S., Brodsky V.I., Outstripping engineering preparation of construction sites/ Applied Mechanics and Materials, 580-583, 2294-2298 (2014)

4. Grigoreva L.S., Oleinik P.P., Modelling of processing construction waste management system . Procedia Engineering, 153, 208-216 (2016)

5. Abramov I.L., Lapidus A.A., Implementing large-scale construction projects through application of the systematic and integrated method. Construction - The Formation of Living Environment conference proceedings, 062002 (2018)

6. Grigoreva L.S., Oleinik P.P., Intentification of facilities for processing of construction waste._Scientific Review , 12, 386-389 (2015) 
7. Oleinik P.P., Brodsky V.I., Grigorieva L.S., Determining the degree of mobility of building systems. Applied Mechanics and Materials, 580-583, 2253-2256 (2014)

8. Azariy L. Integral Potential Effectiveness of Organizational-Technological and Managerial Decisions of Building Object. Applied Mechanics and Materials, 584-586, 2230$2232(2014)$

9. Grigoreva L.S., Prospects for the recycling of construction waste. Natural and technical sciences, 6 (84), 591-593 (2015)

10. Grigoreva L.S., Determination of sustainable values for the parameters of the construction of residential buildings. HRC 2017 (2018)

11. Grigoreva L.S., Oleinik P.P., Recycling waste wood of construction. Materials Science Forum, 871, 126-131 (2016)

12. Abramov I.L., Lapidus A.A., Systemic integrated method for assessing factors construction timelines. MATEC Web of Conf., 05033 (2018)

13. Oleinik P.P., Oleinik S.P. Basic systems for processing construction waste. Housing construction, 5, 24-26 (2005)

14. Lapidus A.A., Makarov A.N. Fuzzy Sets on Step of Planning of Experiment for Organization and Management of Construction Process. MATEC Web of Conf., 05003 (2016) 